\title{
Obituary.
}

Prof. C. Niven, F.R.S.

PROF. CHARLES NIVEN was born in September I 845 , and was one of four brothers who achieved the distinction of being wranglers. He entered the University of Aberdeen as a student in 1859, graduated there with first class honours in mathematics and natural philosophy. In $\mathrm{I} 863$ he proceeded to Trinity College, Cambridge, and in 1867 was senior wrangler. In the same year he was elected a fellow of Trinity College and was appointed professor of mathematics at Cork.

It was during the tenure of the professorship at Cork that the greater part of Prof. Niven's contributions to mathematical and physical science was published. Between I 868 and I880 he produced thirteen papers on various subjects. His first paper, on the application of Lagrange's equations to the solution of questions of impact, was published in the Messenger of Mathematics in 1868 , and, although the method is implicitly involved in Lagrange's general dynamical scheme, its effectiveness in dealing with problems of impulsive motions had previously not been adequately appreciated. This paper, was followed by three papers on the wave surface, a paper on rotatory polarisation in isotropic media published in the Quarterly Journal of Mathematics, papers on the mathematical theory of elasticity in the Transactions of the Royal Society of Edinburgh, the Quarterly Journal of Mathematics, and the Philosophical Magazine, and a paper on a method of finding the parallax of double stars, and on the displacement of the lines in the spectrum of a planet, published in the Monthly Notices of the Royal Astronomical Society. In 1879 he communicated a paper on the conduction of heat in ellipsoids of revolution to the Royal Society, and in I880 a paper on the induction of electric currents in infinite plates and spherical shells; both papers were published in the Philosophical Transactions. These two papers are the most outstanding of Prof. Niven's writings; the analytical skill exhibited in them is very great, and the results obtained are of importance.

In 1880 Prof. Niven was appointed to the chair of natural philosophy in the University of Aberdeen. The demands made on his time by the duties of his professorship and the development of the department appear to have prevented him from pursuing his researches farther. In $\mathrm{r}_{9 \mathrm{I}} 7$, however, he sent to the Admiralty a paper on the theory of the location of sound in water, which was of service in connexion with the campaign against submarines, but the paper was never published. His tenure of the chair at Aberdeen extended from 1880 to 1922 , and during that time the department of natural philosophy increased greatly; in 1880 it was housed at King's College with very inadequate laboratory accommodation, but later it was removed to Marischal College, where new and extended accommodation was provided. The provision of the new laboratories and other rooms for the natural philosophy department at Marischal College was very largely due to Prof. Niven's initiative and energy, and their successful completion added greatly to the efficiency of the department. When natural philosophy was taught at King's College, only a small number of the students obtained any training in experimental work; with the extended accommodation it became possible to give experimental training to a larger number of students and to a greater extent. Additional lecture courses for students proceeding to an honours degree were also instituted.

In March 1922, Prof. Niven developed a serious illness from which he never fully recovered. He retired from the professorship at the end of September 1922, and his many friends hoped that he might enjoy a period of well-earned leisure, but after a few months free from work he died on May Ir.

\section{Mr. E. J. BANField}

The Melbourne Argus announces the death, in May or June last, of Mr. E. J. Banfield, at the age of seventy-one. Mr. Banfield was born in Liverpool on September 4, I852, and was the son of Mr. J. W. Banfield, of Ararat, Victoria. After having been occupied for some years as a journalist, he retired in 1897 , with his wife, to Dunk Island, in lat. $17^{\circ} 55^{\prime} \mathrm{S}$., between the Great Barrier Reef and the Queensland coast. Here he lived the life of a recluse, occupied in cultivating tropical produce, and in observing Nature, but he found time to describe his experiences in three books, "Confessions of a Beachcomber" (r908), "My Tropic Isle" (I9II), and "Tropic Days" (I9I8).

The "Confessions of a Beachcomber" gives an attractive picture of $\mathrm{Mr}$. Banfield's life on Dunk Island. It describes something of his success in adapting himself to his novel surroundings, alone with his wife except for a few natives, and it reveals him as a man of lovable nature, with a pleasant sense of humour, and as an acute observer of Nature. The book is full of the sunshine and luxuriance of the tropics. In vivid word-pictures it describes the birds which visit some gorgeous tree to feed on its honey or its fruit, the productiveness of the banana or the papaw, the habits of stick-insects or leaf-rolling ants, of dugongs, turtles, and sucking-fish, and many more of the charms of the tropics. Wherever Mr. Banfield records his observations he has something instructive to say; and in many cases his narrative is as entertaining as truthful. He tells us that his retirement was prompted by his wish to put into practical operation his regard for the welfare of bird and plant life. "Man destroys birds for sport, or in mere wantonness, and the increasing myriads of insect hosts lay such toll upon his crops and the fruit of the earth which by the exercise of high intelligence and noble perseverance he has improved and made plentiful, that the national loss is to be counted by hundreds of thousands."

Under Mr. Banfield's rule Dunk Island became a sanctuary for birds, many of which became bold and familiar. He did not hesitate to incur financial losses in order to remain true to his principles. A promising attempt at bee-keeping was relinquished because of the depredations of two species of bee-eating birds, which he would not interfere with in order to save his bees. His death, which took place on the island, was reported by a passing steamer, to which his wife had signalled for assistance. His writings are well worth the attention of zoologists, botanists, and ethnologists, who will find them to contain much that is illuminating and interesting.
S, F. H. 